\title{
Morfin eller oksykodon tabletter mot smerter?
}

\author{
Morfin og oksykodon er to sterke opioider. Begge finnes som depot- \\ tabletter og ordinære (hurtigvirkende) tabletter. Indikasjonene er de \\ samme for begge to, nemlig sterke smerter - kreftsmerte, kronisk \\ ikke-malign smerte og akutt postoperativ smerte. Det er ikke vist at \\ det ene midlet er å foretrekke fremfor det andre.
}

Se også kunnskapsprøve på www.tidsskriftet.no/quiz
Olav Magnus S. Fredheim

olav.m.fredheim@ntnu.no

Nasjonalt kompetansesenter for sammensatte lidelser

og

Norges teknisk-naturvitenskapelige universitet og

Klinikk for akuttmedisin

Sykehuset Telemark

Ola Dale

Norges teknisk-naturvitenskapelige universitet og

Klinikk for anestesi og akuttmedisin

St. Olavs hospital

\section{Stein Kaasa}

Norges teknisk-naturvitenskapelige universitet og

Kreftavdelingen

St. Olavs hospital

Petter C. Borchgrevink

Nasjonalt kompetansesenter for sammensatte lidelser

og

Norges teknisk-naturvitenskapelige universitet og

Avdeling for smerte og sammensatte lidelser St. Olavs hospital

Data fra reseptregisteret viser at det antall personer som fikk forskrevet oksykodon som ledd i palliativ behandling for kreftsykdom, økte fra om lag 3400 i 2004 til om lag 5800 i 2007. I samme periode steg antallet som hvert år fikk oksykodon på andre indikasjoner fra 2600 til 6700 (fig 1) (1). Tilsvarende var det en økning i forskrevet mengde, målt i definerte døgndoser (DDD). Samtidig falt forskrivningen av morfin målt i definerte døgndoser med $13 \%$ for palliativ behandling og med $15 \%$ for andre indikasjoner. Det var også færre mennesker som fikk forskrevet morfin. Finnes det kliniske studier som støtter denne dreiningen mot bruk av oksykodon fremfor morfin?

\section{Materiale og metode}

Denne artikkelen er basert på gjennomgang av nyere oversikter og metaanalyser om bruk av opioider i klinisk virksomhet. Aktuelle artikler ble identifisert $\mathrm{i}$ forfatternes personlige arkiv og gjennom ikke-systematiske søk i PubMed. Søkene i PubMed skulle også identifisere eventuelle nye kliniske studier der man sammenlikner morfin og oksykodon. Disse skulle ikke være inkludert i tidligere oversiktsartikler. Det er kun bruk av oksykodon og morfin i tablettform som behandles her.

Forfatterne er medlemmer av en tverrfaglig forskningsgruppe om smerte og palliasjon.

\section{Farmakokinetikk og farmakodynamikk}

I tabell 1 sammenliknes de klinisk-farmakologiske egenskapene til morfin og oksykodon. Dette er et anslag ut fra forskjellige kilder (2-4), og det er betydelig variasjon, både interindividuelt og studiene imellom.

Morfin er mindre potent enn oksykodon og kan ha langsommere anslag. Langsommere anslag kan ha betydning ved administrasjon etter behov, men ikke ved fast dosering over tid. Morfin og oksykodon har begge sin hovedvirkning via $\mu$-opioidreseptor. Det er eksperimentelle holdepunkter for å anta at oksykodon også virker på א-reseptor, men dette er ikke bekreftet i kliniske studier (4). Morfin har på grunn av høy førstepassasjemetabolisme lavere biotilgjenglighet enn oksykodon, men det er ingen store forskjeller i de farmakokinetiske variablene «tid til maksimal serumkonsentrasjon» $\left(\mathrm{T}_{\text {maks }}\right)$, distribusjonsvolum $\left(\mathrm{V}_{\mathrm{ss}}\right)$, clearance og terminal halveringstid.

De viktigste forskjellene mellom morfin og oksykodon er knyttet til metabolismen. Morfin elimineres i hovedsak ved konjugering til glukuronsyre. Den ene metabolitten, morfin-6-glukuronid (M-6-G), er et analgetikum selv og bidrar til morfinets totale kliniske virkning ved vedvarende langtidsbruk. Nyresvikt kan gi akkumulasjon av morfin-6glukuronid, med fare for sedasjon og respirasjonshemming ved langvarig bruk. I praksis reduseres imidlertid faren for respirasjonshemming ved at pasienter som bruker opioider, over tid utvikler toleranse.
Oksykodon elimineres i hovedsak via CYP-mediert metabolisme. Den inaktive hovedmetabolitten noroksykodon dannes via CYP3A4. Den andre viktige primærmetabolitten, oksymorfon, dannes via CYP2D6. Oksymorfon er omtrent ti ganger så potent som morfin, men siden den bare representerer $10 \%$ av den totale metabolismen, er det uavklart om den har klinisk betydning. Imidlertid er det nylig rapportert at CYP2D6polymorfismene som gir lav metabolisme («poor metabolizers»), har lavere oksymorfon-oksykodon-ratio enn normalvarianten av genet for CYP2D6 (villtypen) (5).

Forskjellen i metabolisme har betydning for sannsynligheten for at det kan oppstå farmakokinetiske interaksjoner med andre medikamenter. Det finnes noen få rapporter om slike interaksjoner som involverer morfin, og der er rifampicin, cimetidin, klomipramin og forskjellige antikonseptiver de viktigste. Når det gjelder CYP2D6 og CYP3A4, er det et stort potensial for farmakokinetiske interaksjoner (6). For eksempel vil potent hemming av CYP2D6 kunne føre til sterkt redusert danning av oksymorfon, mens hemming eller induksjon av CYP3A4 kan gi henholdsvis økt eller nedsatt serumnivå av oksykodon - med økt eller minsket effekt til følge. Det er nylig vist at rifampicin gjennom induksjon øker metabolismen av oksykodon og dermed fører til redusert effekt (7). Den kliniske betydningen av oksykodonets øvrige interaksjonspotensial er imidlertid ikke avklart.

\section{Akutt postoperativ smerte}

I en randomisert, kontrollert studie om postoperativ smerte ble depotformuleringer av $20 \mathrm{mg}$ og $40 \mathrm{mg}$ oksykodon sammenliknet med $45 \mathrm{mg}$ og $90 \mathrm{mg}$ morfin (8). Studien viste at effekten var sammenliknbar for både maksimal smertelindring, bivirkninger og total smertelindring. Depotformuleringer av opioider brukes i noen grad som del av postoperativ basisanalgesi.

Imidlertid må man ved behandling av

\section{Hovedbudskap}

- Morfin og oksykodon er effektivt mot både kreftsmerte, kronisk ikke-malign smerte og akutt smerte

- Det er ikke påvist det ene midlet har bedre effekt enn det andre 


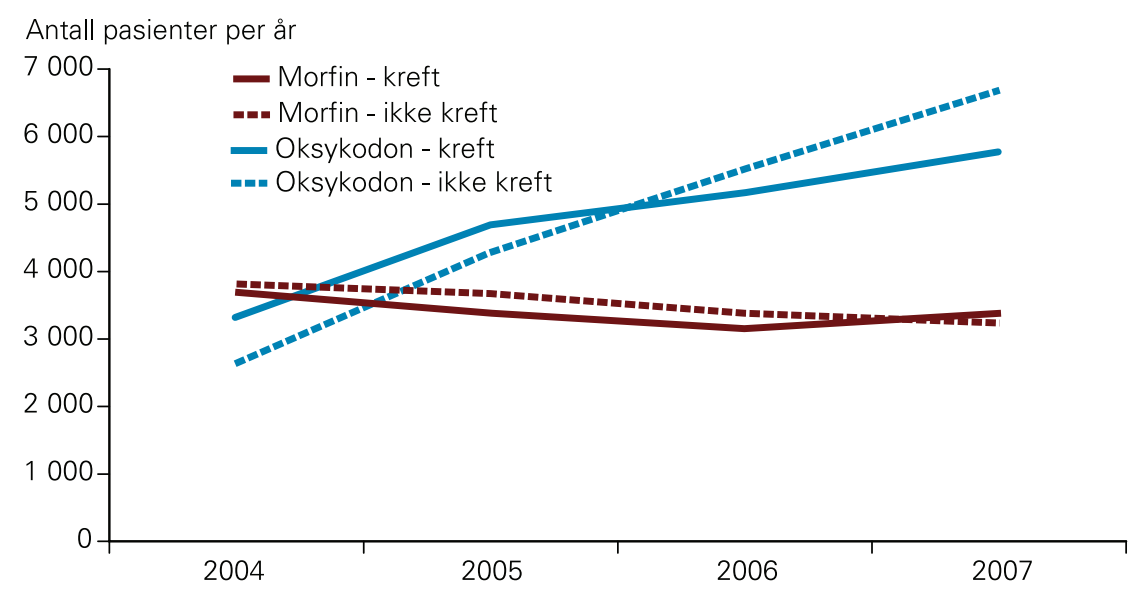

Figur 1 Utviklingen i forskrivning av oksykodon og morfin i Norge fra 2004 til 2007 ut fra Fredheim og medarbeideres artikkel (1). Figuren viser antall personer som har fått utlevert hvert av medikamentene hvert år

akutte smerter med depotformuleringer være oppmerksom på den lange halveringstiden og at det kan ta flere timer å nå maksimal effekt. Depotformuleringer bør ikke brukes etter behov eller til rask titrering av dosen. Vi kjenner ikke til andre randomiserte, kontrollerte studier der morfin- og oksykodontabletter for akutt postoperativ smerte er sammenliknet.

\section{Kronisk ikke-malign smerte}

Spørsmålet om hvorvidt det $\mathrm{i}$ behandlingen av kronisk ikke-malign smerte er grunnlag for å anbefale depotformuleringen av ett bestemt opioid fremfor de øvrige opioidene er vurdert i flere systematiske oversiktsartikler de siste årene. Ikke i noen av disse oversiktene er det konkludert med at det er grunnlag for å anbefale ett bestemt middel som førstevalg $(9,10)$. Imidlertid finnes det få rando-

miserte studier der man har sammenliknet to opioider direkte.

\section{Kreftsmerte}

I en fersk metaanalyse omkring oksykodon versus morfin og hydromorfon $\mathrm{i}$ behandling av kreftsmerte ble det ikke funnet indikasjoner på at oksykodon skilte seg fra de øvrige opioidene med tanke på effekt eller bivirkningsprofil (11). Dette samsvarer med funnene $i$ en Cochrane-oversikt om bruken av oral morfin mot kreftsmerte og i en norsk kunnskapsoppsummering $(12,13)$. Imidlertid er det rapportert lavere prevalens av hallusinasjoner ved bruk av oksykodon sammenliknet med morfin for kreftsmerte $(4,13)$.

\section{Opioidrotasjon}

I flere studier er det vist at pasienter som får uakseptable bivirkninger av ett opioid, kan

Tabell 1 Klinisk-farmakologiske karakteristika for morfin og oksykodon tabletter (2-4)

\begin{tabular}{|c|c|c|}
\hline & Morfin & Oksykodon \\
\hline Oral biotilgjenglighet (\%) & $\sim 20-30$ & $\sim 60-90$ \\
\hline${ }^{1} \mathrm{~T}_{\text {maks }}(\mathrm{t})$ Ordinære tabletter & $\sim 0,7$ & $\sim 1,0$ \\
\hline Depottabletter & $1,7-2,7$ & $1,3-3,2$ \\
\hline Clearance (l/min) & $\sim 1,0$ & $\sim 0,8$ \\
\hline Distribusjonsvolum $\left(\mathrm{V}_{\mathrm{ss}}\right)(\mathrm{l})$ & $\sim 200$ & $\sim 150$ \\
\hline Halveringstid $\left(\mathrm{t}_{1 / 2}\right)(\mathrm{t})$ & $\sim 2$ & $\sim 2,5$ \\
\hline Eliminasjon & UGT2B7 & $\begin{array}{l}\text { CYP3A4 } \\
\text { CYP2D6 }\end{array}$ \\
\hline Aktive metabolitter & Morfin-6-glukuronid & Oksymorfor \\
\hline Interaksjonspotensial & Lite & Betydelig \\
\hline Virkningsmekanisme (reseptor) & $\mu$ & $\mu(\kappa)$ \\
\hline Ekvianalgetisk ratio² (oksykodon/morfin) & & $0,5-0,75$ \\
\hline Anslagstid (t) (intravenøs administrasjon) & 0,75 & 0,50 \\
\hline
\end{tabular}

ha nytte av å bytte til et annet - såkalt opioidrotasjon. Fordi morfin er det som er mest brukt som førstelinjeopioid, er rotasjon fra morfin til oksykodon mer studert enn rotasjon fra oksykodon til morfin. Disse studiene har vist at en stor del av dem som har dårlig respons på morfin, har nytte av å bytte til oksykodon $(14,15)$.

Imidlertid er det fra en studie med pasienter med kronisk ikke-malign smerte rapportert at ved bruk av oksykodon som førstelinjeopioid var det indikasjon for å rotere til annet opioid hos $67 \%$, mens det samme gjaldt $58 \%$ i morfingruppen (16). Svakheter ved den aktuelle studien er at pasientene ikke var randomisert til de ulike førstelinjeopioidene, og at det bare var henholdsvis 33 og 18 pasienter i hver gruppe. En annen studie har vist at det er overhyppighet av en genetisk variant hos dem som har dårlig effekt av morfin og derfor trenger opioidrotasjon (17). Tilsvarende farmakogenetiske studier av oksykodon er ikke utført.

\section{Metodologiske vurderinger}

En svakhet ved studiene der bruken av morfin og oksykodon er sammenliknet, er at det er brukt forskjellige ratioer til beregning av likeverdige doser. Det er grunn til å anta at resultatene fra de randomiserte studiene kan være avhengige av valgt ratio. Både for morfin- og oksykodontabletter er det i placebokontrollerte studier i ulike pasientpopulasjoner vist god effekt. Oppsummering av studier som sammenligner ett og ett opioid med placebo, er imidlertid dårligere egnet enn direkte sammenlikninger av de aktuelle midlene for å kunne konkludere om ett bestemt opioid bør foretrekkes fremfor de øvrige.

\section{Dyrestudier og eksperimentelle humane studier}

Eksperimentelle dyrestudier har gitt opphav til spekulasjoner om at oksykodon og morfin har ulike virkningsmekanismer, og at oksykodon skulle være bedre egnet enn morfin i behandlingen av nevropatisk smerte (18). Imidlertid er det stor forskjell på eksperimentelle smertemodeller med gnagere og pasienter med nevropatisk smerte. Det er derfor ikke grunnlag for å hevde at resultatene fra slike dyrestudier bør få konsekvenser for klinisk praksis før kliniske humane studier har vist forskjell mellom morfin og oksykodon når det gjelder effekt på smerter og/eller bivirkninger (19). Eksperimentelle humane studier publisert de siste årene har også indikert at oksykodon kan være mer effektivt enn morfin mot visceral smerte (20).

\section{Praktiske forhold}

I Norge er både morfin og oksykodon på markedet som depottabletter, tabletter, mikstur og injeksjonsvæske. Morfin er i tillegg tilgjengelig som depotgranulat til mikstur. Følgelig har dette midlet en praktisk 
fordel som førstelinjeopioid ved at depotformuleringen kan gis til pasienter med svelgevansker. Dette momentet er særlig aktuelt ved palliativ behandling, der det kan være behov for å skifte over fra vanlige tabletter til andre perorale administrasjonsformer og videre til parenteral administrasjon etter hvert som sykdommen progredierer.

\section{Legemiddeløkonomi}

En sammenlikning av brukskostnadene for morfin- og oksykodontabletter vanskeliggjøres av flere faktorer. Den første faktoren er at det for oksykodontabletter finnes en veiledende pris, dessuten at trinnprisen er lavere. Den andre er at dersom man legger til grunn en ekvianalgetisk ratio på 0,5 mellom oksykodon og morfin peroralt (21), er det ikke tilgjengelig depottabletter med identisk analgetisk effekt for høyere doser enn $5 \mathrm{mg}$ oksykodon, som svarer til $10 \mathrm{mg}$ morfin. I tillegg varierer prisene per tablett ut fra pakningsstørrelsen.

For å få et inntrykk av kostnadsforholdet har vi gjort noen enkle beregninger med priser hentet fra Felleskatalogen for 2009 (22) (e-ramme 1). Beregningene viser at prisforholdet avhenger av tablettstyrke og formulering. På grunn av trinnprissystemet vil depotformuleringer av oksykodon være rimeligere enn depotformuleringer av morfin når forskrivningen omfattes av trinnprissystemet. Morfin vil i de fleste tilfeller være rimeligere ved forskrivning av hurtigvirkende tabletter eller ved forskrivninger av depottabletter som ikke omfattes av trinnprissystemet.

Det foreligger data som indikerer at den ekvianalgetiske ratio mellom oksykodon og morfin varierer mellom 0,5 og 1 hos ulike pasienter (21). Dersom den gjennomsnittlige ekvianalgetiske ration er høyere enn 0,5 , påvirkes prisforholdet i favør av morfin. Et viktig poeng knyttet til legemiddeløkonomi er at prisbildet har endret seg vesentlig de siste to årene på grunn av innføring av trinnprissystemet. Det kan ventes ytterligere fall i prisene på oksykodon pga. trinnprissystemet og utløp av patent. Økningen i bruken av oksykodon har altså funnet sted i en periode der morfin hadde en større prisfordel enn det som er tilfellet i dag. I fremtiden kan situasjonen bli slik at kostnadene for de to legemidlene er tilnærmet likeverdige.

\section{Konklusjon}

Både oksykodon og morfin gir effektiv smertelindring når opioider er indisert for kreftsmerte, kronisk ikke-malign smerte eller akutt postoperativ smerte. Ved alle tre indikasjonene er datagrunnlaget for spinkelt til at man kan trekke slutninger om hvorvidt medikamentene er likeverdige eller om man bør foretrekke det ene. Så lenge det ikke er holdepunkter for å hevde at det ene opioidet er bedre enn det andre, ser vi ikke grunn til å fravike internasjonale anbefalinger om at morfin er førstevalget ved kreftrelatert smerte (23).

Ved kronisk ikke-malign smerte og akutt smerte foreligger det ikke vektige argumenter for å foretrekke det ene legemidlet fremfor det andre. Fordi økningen i bruk av oksykodon de siste årene har vært større enn reduksjonen i bruk av morfin, er det grunn til å tro at behandlingen av kreftsmerte og akutt smerte er blitt bedre på grunn av økt samlet bruk av sterke opioider.

Oppgitte interessekonflikter: Ola Dale mottok i 2005 forelesningshonorar knyttet til et arrangement i regi av Mundipharma, Stein Kaasa er scientific advisor i Nycomed og har fått betaling for foredrag fra Cephalon. De andre forfatterne har ingen oppgitte interessekonflikter.

e-ramme 1 finnes i artikkelen på

www.tidsskriftet.no

\section{Litteratur}

1. Fredheim OM, Skurtveit S, Breivik H et al. Increasing use of opioids from 2004 to 2007 - pharmacoepidemiological data from a complete national prescription database in Norway. Eur J Pain 2010; 14: $289-94$

2. Gourlay GK. Sustained relief of chronic pain. Phar macokinetics of sustained release morphine. Clin Pharmacokinet 1998; 35: 173-90.

3. Hasselstrom J Sawe J. Morphine pharmacokinetics and metabolism in humans. Enterohepatic cycling and relative contribution of metabolites to active opioid concentrations. Clin Pharmacokinet 1993; 24: 344-54

4. Kalso E. Oxycodone. J Pain Symptom Manage 2005; 29: S47-S56.

5. Zwisler ST, Enggaard TP, Noehr-Jensen $L$ et al. The hypoalgesic effect of oxycodone in human experimental pain models in relation to the CYP2D6 oxidation polymorphism. Basic Clin Pharmacol Toxicol 2009; 104: 335-44.

6. Spigset O, Molden E. Cytokrom P-450 3A4 - kroppens viktigste arena for legemiddelinteraksjoner. Tidsskr Nor Legeforen 2008; 128: 2832-5

7. Nieminen TH, Hagelberg NM, Saari TI et al. Rifampin greatly reduces the plasma concentrations of intravenous and oral oxycodone. Anesthesiology 2009: 110: 1371-8.

8. Curtis GB, Johnson GH, Clark P et al. Relative potency of controlled-release oxycodone and controlled-release morphine in a postoperative pain model. Eur J Clin Pharmacol 1999; 55: 425-9.

9. Chou R, Clark E, Helfand M. Comparative efficacy and safety of long-acting oral opioids for chronic non-cancer pain: a systematic review. J Pain Symptom Manage 2003; 26: 1026-48.

10. Chou R, Fanciullo GJ, Fine PG et al. Clinical guidelines for the use of chronic opioid therapy in chronic noncancer pain. J Pain 2009; 10: 113-30.

11. Reid CM, Martin RM, Sterne JA et al. Oxycodone for cancer-related pain: meta-analysis of randomized controlled trials. Arch Intern Med 2006; 166 : $837-43$.

12. Kongsgaard UE, Kaasa S, Dale 0 et al. Lindring av smerter hos kreftpasienter. Rapport nr. 9-2005. Oslo: Nasjonalt kunnskapssenter for helsetjenesten, 2005

13. Wiffen PJ, McQuay HJ. Oral morphine for cancer pain. Cochrane Database Syst Rev 2007; CD003868: DOI: 10.1002/ 14651858.CD003868.pub2.

14. Narabayashi M, Saijo Y, Takenoshita S et al. Opioid rotation from oral morphine to oral oxycodone in cancer patients with intolerable adverse effects: an open-label trial. Jpn J Clin Oncol 2008; 38: $296-304$

15. Riley J, Ross JR, Rutter D et al. No pain relief from morphine? Individual variation in sensitivity to morphine and the need to switch to an alternative opioid in cancer patients. Support Care Cancer 2006; 14: 56-64.

16. Quang-Cantagrel ND, Wallace MS, Magnuson SK. Opioid substitution to improve the effectiveness of chronic noncancer pain control: a chart review. Anesth Analg 2000; 90: 933-7.

17. Ross JR, Rutter D, Welsh K et al. Clinical response to morphine in cancer patients and genetic variation in candidate genes. Pharmacogenomics J 2005; 5: 324-36.

18. Nielsen CK, Ross FB, Lotfipour S et al. Oxycodone and morphine have distinctly different pharmacological profiles: radioligand binding and behavioural studies in two rat models of neuropathic pain. Pain 2007; 132: 289-300.

19. Kalso E. How different is oxycodone from morphine? Pain 2007; 132: 227-8

20. Lemberg K, Heiskanen T, Kontinen VK et al. Pharmacology of oxycodone: does it explain why oxycodone has become a bestselling strong opioid? Scand J Pain 2009: 1: S18-S23.

21. Anderson R, Saiers JH, Abram S et al. Accuracy in equianalgesic dosing. Conversion dilemmas. J Pain Symptom Manage 2001; 21: 397-406.

22. Felleskatalog over farmasøytiske spesialpreparater markedsført i Norge. Oslo: Felleskatalogen A/S, 2009. www. felleskatalogen.no (10.9.2009).

23. Hanks GW, Conno F, Cherny N et al. Morphine and alternative opioids in cancer pain: the EAPC recommendations. Br J Cancer 2001; 84: 587-93.

Manuskriptet ble mottatt 22.9. 2009 og godkjent 22.4. 2010. Medisinsk redaktør Petter Gjersvik. 